\title{
Washington Economic Agreement and the Implementation of Structural Policies in Bosnia and Herzegovina
}

\section{Dr. Edita Đapo}

International University of Sarajevo

\section{Dr. Ognjen Riđić}

International University of Sarajevo

\begin{abstract}
The Washington Consensus (WC) development approach consists of three macroeconomic and seven structural policies for transitional transformation of the economy. Proper implementation of the structural policies was important for qualitative changes in the economy. In this paper, we will explain and evaluate the implementation of seven structural policies, being: improvement of the legal system and governance, privatization, foreign direct investment (FDI), deregulation, redirecting public expenditures, trade liberalization and tax reform, over time. This paper will also make comparisons with other transitional countries in the region, in order to draw the lessons and make recommendations for the future development of $\mathrm{B} \& \mathrm{H}$. It can be concluded that $\mathrm{B} \& \mathrm{H}$ has been stagnating in its economic development, and that B\&H's government must improve its tax system, governance, engage in the fight against corruption, speed up the business deregulation and privatization in order to accelerate the economic growth.
\end{abstract}

Keywords: Washington Consensus, Structural Policies, Bosnia and Herzegovina. 


\section{INTRODUCTION}

Williamson (1999) explained the importance of so called "Washington Consensus" dividing it into two sets of policies: macroeconomic $^{1}$ and structural policies. Structural policies are economic policies for developing and transitionalcountries that have been promoted by the International Monetary Fund (IMF) and the World Bank (WB).The transitional countries were advised to implement the structural policies that were needed to remove the government control, create private ownership in the economy, undertake business deregulation and promote the market competition. The implementation of these policies had the aim to move the economy towards market-determined methods of allocating resources, making production decisions and distributing output, (i.e. to create the environment that would help the economy to achieve long-term and sustainable growth).

In this paper, we will evaluate the implementation of these structural policies in $\mathrm{B} \& \mathrm{H}$. It is of the crucial importance to analyse the progress and the way of implementation of these policies and highlight the problems that occurred in order to propose a certain recommendation to ensure the future economic development. The paper is organized, as follows: Section 2 discusses the legal system and governance, section 3 explains the progress with privatization, section 4 addresses the evaluation of FDIs, deregulation and inflows, section 5 presents the evaluation of the business deregulation, section 6 evaluates the redirection of public expenditures, section 7 describes the progress towards free trade, section 8 gives an explanation about tax reforms, and section 9 , concludes.

\section{DISCUSSION}

\subsection{Legal system and governance}

Bosnia and Herzegovina's system of governance was established by the Dayton Peace Accords. The government is highly complex, fragile and politically dysfunctional with the complicated decisionmaking system. Bosnia and Herzegovina has 14 governments (1 at state level, 2 at entity level, 10 cantonal in the Federation entity of B\&H (F.B\&H), and 1 for the District of Brcko). Under the Dayton

\footnotetext{
${ }^{1}$ For evaluation of the implementation of macroeconomic policies see Dapo \& Ridic (2015).
} 
Peace Accords, B\&H has a very weak central government, with substantial powers delegated to theentity levels of government. Within the Federation entity, the power is further decentralized into ten (10) cantons: there are 4 Croat and 4 Bosniak cantons; the other 2 are mixed. The cantons have a high degree of autonomy and possess their own constitutions, parliaments, health care ministries and governments. Municipalities in the Federation exercise self-government and are elected democratically. The Constitution of the Federation does not, however, spell out the specific powers of municipal governments; this is done at the level of the cantons. Although, the Serb Republic (RS) is organized as a centralized, unitary entity, there have been frequent calls for a more regional approach to governmental organization. Under an arbitration ruling in 1999, District of Brcko has a separate status from the two entities. Although the Federation and the Serb Republic technically share sovereignty over the area, it is in effect a third entity whose government is under the authority of the international community. In March of 2000, the High representative formally established the institutions of the District, including its own Parliament, Constitution, and budgetary independence (OHR, 1999).

This complex and not transparent government cannot make prompt and adequate decision regarding any issue. This causes delays in the policy realization. Besides complexity, frequent changes in the composition of the government cause changes of the policies that are to be implemented. Politicians, usually fail to reach the consensus on the economic and social issues. Generally, most governments and public administrations in B\&Hoperate with little transparency. In June of 2001, however, the entities and the central government adopted a Law on Freedom of Information that obliges governments to disclose information to the public. Freedom House yearly publishes the ratings for the strength of the governments worldwide, as well as the progress in certain policy implementation using the National Democratic Governance index, as it can be seen in Table 1, below:

Table 1: Nations in Transition Rating for Bosnia and Herzegovina

\begin{tabular}{|c|c|c|c|}
\hline Year & $\begin{array}{c}\text { Democratic } \\
\text { Governance }\end{array}$ & $\begin{array}{c}\text { Judicial } \\
\text { Framework and } \\
\text { Independence }\end{array}$ & Corruption \\
\hline 2000 & 6 & 6 & 6 \\
2005 & 4,75 & 4,25 & 4,5 \\
2010 & 5,25 & 4 & 4,5 \\
2014 & 5,75 & 4,25 & 4,75 \\
\hline
\end{tabular}

Source: (Freedom House, 2014). 
The ratings are based on a scale from " 1 " to " 7 ", with " 1 " representing the highest level and " 7 " the lowest level of democratic development. The 2005 year ratings' reflect the period from January 1 through December 31, of 2004(i.e. of the previous year).

Furthermore, non-transparency of the government is the main source of corruption, which is the key obstacle to the economic reform and the establishment of the rule of law in $\mathrm{B} \& \mathrm{H}$. The problem of corruption is widely acknowledged by the international and domestic organizations, the domestic press and population. According to the Centers for Civic Initiatives Report in 2014, which monitors the efficiency of agencies and assemblies at all levels of power, the governmental dysfunction fueled by partisan conflicts in F.B\&H has affected living conditions. The Federation's debt has grown to more than $€ 300$ million ( $\$ 330.2$ million) as budget funds were sunk in the corruption or used to buy social peace at the expense of the investment.

According to the Freedom House's Nation in Transition Reports (2014), B\&H has made some progress in strengthening the governance, improving the judicial system and decreasing the corruption, by 2005 . However, the negative trend in governance is recorded, since 2005, while the political influence on jurisdiction system, as well as the corruption, increased from 2010 to 2014 . To have a clearer picture where $\mathrm{B} \& \mathrm{H}$ is now and what progress have been made regarding the changes of the government during transition, we will compare $\mathrm{B} \& \mathrm{H}$ with other countries in transition. Table 2 presents the changes in rating averages for transition countries,ranging from 1999, 2005 and 2014.

Table 2: Rating for Transition Countries

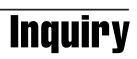

$2015 / 2$

\begin{tabular}{|l|c|c|c|c|c|c|c|c|c|}
\hline & \multicolumn{3}{|c|}{ Governance } & \multicolumn{3}{c|}{$\begin{array}{c}\text { Judicial } \\
\text { Framework }\end{array}$} & \multicolumn{3}{c|}{ Corruption } \\
\cline { 2 - 12 } & 2000 & 2005 & 2014 & 2000 & 2005 & 2014 & 2000 & 2005 & 2014 \\
\hline Albania & 4,7 & 4,25 & 4,75 & 5 & 4,5 & 4,75 & 6 & 5,25 & 5,25 \\
\hline B\&H & 6 & 4,75 & 5,75 & 6 & 4,25 & 4,25 & 6 & 4,5 & 4,75 \\
\hline Croatia & 4 & 3,5 & 3,5 & 4,75 & 4,5 & 4,5 & 5,25 & 4,75 & 4 \\
\hline Macedonia & 3 & 4 & 4,25 & 4,25 & 3,75 & 4,25 & 5 & 5 & 4,25 \\
\hline Serbia & 5,5 & 4,75 & 3,75 & 5,75 & 4,75 & 4,5 & 6,25 & 5 & 4,25 \\
\hline Montenegro & 5,5 & 4,75 & 4,25 & 5,75 & 4,75 & 4 & 6,25 & 5 & 5 \\
\hline
\end{tabular}

Source: (Freedom House, 2014). Nations in Transition, Selected Years. 
Comparing with other countries in the South East European region $\mathrm{B} \& \mathrm{H}$ has made the greatest progress by 2005 . However, after 2005 the indicators for $\mathrm{B} \& \mathrm{H}$ are showing that the situation is not improving.

\subsection{Privatization}

As we stated in the previous part the government structure in $\mathrm{B} \& \mathrm{H}$ is very complex. Completely different economic policies were performed in two entities. Perfect case to understand it is being exemplified inthe process of privatization; two different procedures were established in order to privatize state property. Mass privatization through free vouchers was adopted in $\mathrm{B} \& \mathrm{H}$ and was implemented by two privatization agencies. However, in both entities, the ruling parties were in control of the process, which caused a disproportionate distribution of vouchers to ethnic majorities. The voucher distribution process in Republika Srpska, which, unlike in Federation, required the citizens to register, in order to receive vouchers, exacerbated the already existent and implicit discrimination against minorities, refugees and displaced persons. There are reports that RS authorities permitted, by the war activities, displaced Serbs from Croatia to register for privatization, despite the fact that non-citizens are notsupposed to be eligible to participate. These trends point out to a clear ethnic bias in the registration process in order to increase the number of entities' ethnic majority, in the process. This conclusion becomes even more significant given the method utilized for valuing vouchers in RS. While in the F. B\&H vouchers do have a face value, in RS the value of the voucher depends on the number of investors interested in a given company. The greater the number of investors, the lower the value of each voucher invested. Without question, the war and perhaps criminal fortunes were recycled throughsome of the privatization deals, in spite of the efforts to ensure the procedural correctness (Buff, 2000: 4).

However, after the year 2000, both entities accepted the sales model for privatization of the state owned enterprises. According to Ministry of Foreign Trade and Economic Relations (2007) the privatization advanced much quicker in RS, where about $62.5 \%$ of the available state capital was privatized by mid-2007. About $45 \%$ of the share value of enterprises was privatized through the vouchers. This approach to privatization was adopted, as a type of social policy, in response to the post war poverty. In the F.B\&H, where authority 
for privatization was invested incantons, as well, only $41 \%$ of property was privatized by mid-2007 (MFTEC, 2007). According to Handjiski (2009), the share of theprivate sector in B\&H's GDP was just over 50 percent, in 2006. In RS, main strategic enterprises in the telecommunication and energy sectors were privatized, while in F. $\mathrm{B} \& \mathrm{H}$, this kind of privatization, still, did not take place.

\subsection{Foreign Direct Investment (FDI)}

The Washington Consensus (WC) approach to the development is based on the assumption thatintroducing the market mechanism and eliminating restrictions on the private sector and trade will produce an improved investment climate, stimulate competitiveness and economic activities. It has been recognized in the economic theory that the benefits of FDI for the host country can be significant, including knowledge and technology transfer to domestic firms and the labor force productivity spillovers, enhanced competition, and improved access for exports abroad, notably, in the source country (Demekas et al, 2005), (Botric, 2010). Due to the low domestic savings there is a need for attraction of FDI to ensure the future economic growth of the country (Botric, 2010). The economists agree that the benefits of FDI tend to significantly outweigh its costs for host countries (Demekas et al, 2005).

Predictable policy environment that promotes the macroeconomic stability, ensures the rule of law and the enforcement of contracts, minimizes distortions, supports competitiveness, and encourages private sector development can be expected to stimulate allprivate including foreign investments (Demekas et al, 2005). Among the macroeconomic and political environmental factors, it is the political stability, as the most important factor that influences the investment decisions. Furthermore, in the case of the institutional environment, the protection of the investors is one of the most important factors. Examples of those can be: the tax systems, lack of corruption, the ease of starting up a company, contract law, transparency, safeguarding of property rights and efficiency of justice (Ilgun, 2009). 
Graph 1: FDI inflows from 1992-2014, by sectors

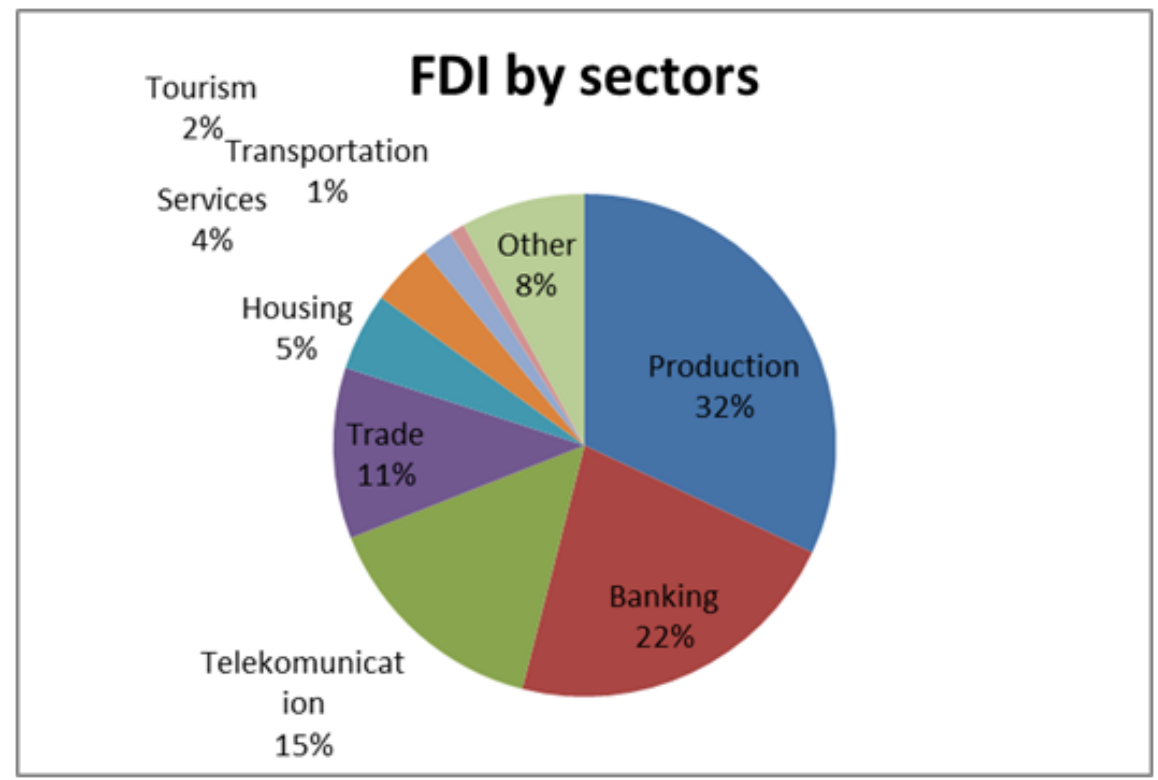

Source: (Central Bank of B\&H, 2015).

The measures aimed directly at promoting the investment are important for some limited period of time. To date, the experiences of foreign investors have been positive in thebanking sector of Bosnia and Herzegovina.

Graph 2: FDI inflows in B\&H

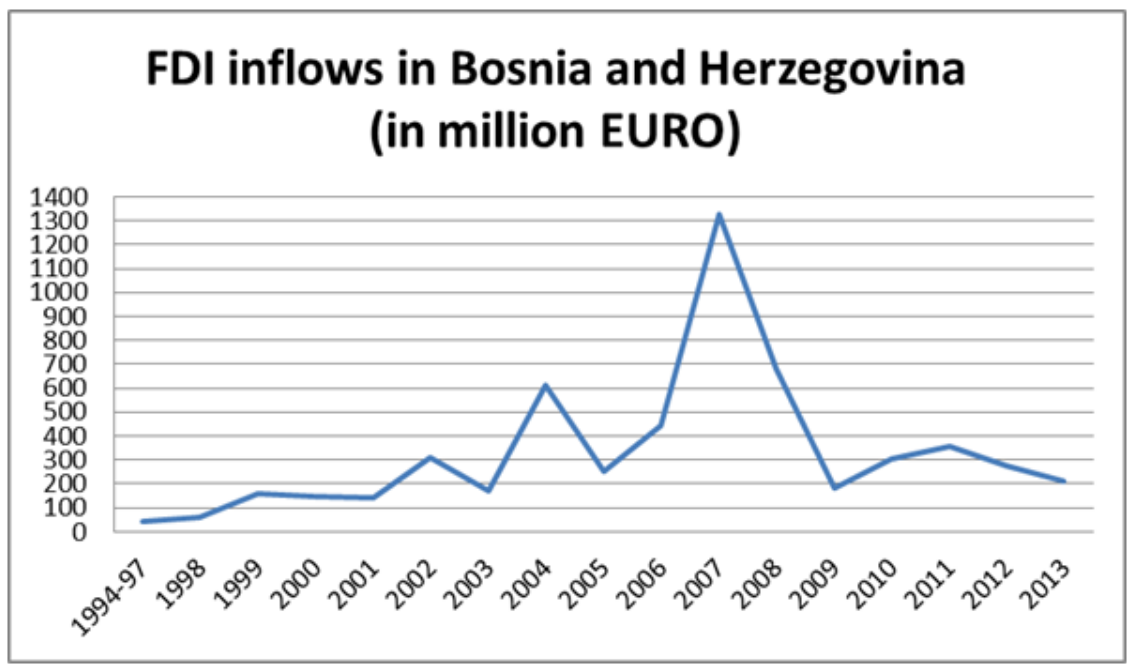


Besides the above mentioned detriments, $\mathrm{B} \& \mathrm{H}$ is unfortunately associated with a high level of corruption. B\&H still has a very complex legal and regulatory framework, a heavy public administrative system, very complex procedures to register new businesses and weak judicial structures. Laws and regulations at the state, entities', cantonal and municipality levels are often contradictory or duplicative (Ilgun, 2009).

Many aspects of the regulatory quality reforms have stagnated over a number of years, making $\mathrm{B} \& \mathrm{H}$ among the least competitive economies in the South East European region. To enhance the prospects of the country, as a destination for the foreign investment, the government established the Foreign Investment Promotion Agency (FIPA) and adopted various incentives for foreign investors. However, analyzing the macroeconomic data it can be seen that the inflow of FDI into Bosnia and Herzegovina was quite low, several percentage of GDP: $12 \%$ in $2007,1.4 \%$ in 2009, 2.7\% in 2014 (FIPA, 2014).

\subsection{Business Deregulation:}

Entities' governments in B\&H removed all barriers regarding free entry of enterprises into the certain industries. However, in order to create and improve the business climate B\&Hneeds to accelerate the Economic Reform process through Compact for Growth proposed by the EU Delegation in $\mathrm{B} \& \mathrm{H}$. The aim of $\mathrm{B} \& \mathrm{H}$ is to eliminate the legal and administrative obstacles for doing business in $\mathrm{B} \& \mathrm{H}$, as well as create more attractive business environment (EU Delegation in $\mathrm{B} \& \mathrm{H}$, 2014).

Figure 3: Ease of Doing Business Ranking

\section{Ease of Doing Business Ranking}

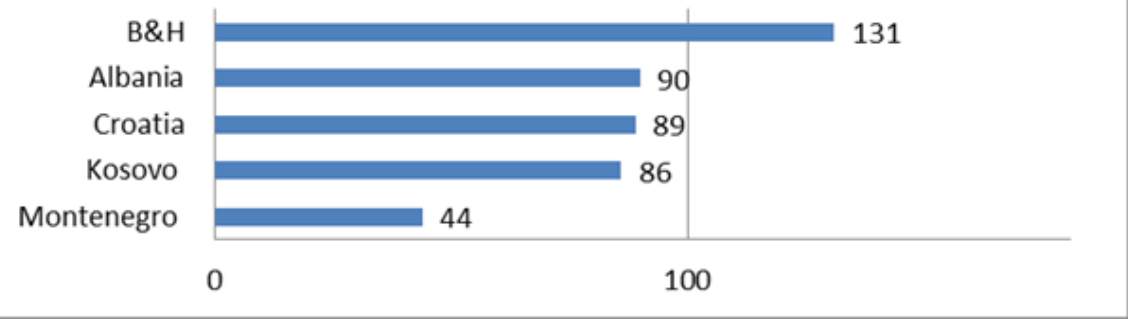

Source: (Doing Business, 2014). 
Many aspects of the regulatory quality reforms have stagnated over a number of years, making B\&H among the least competitive economies in Europe and Central Asia (ECA) regions. B\&H currently ranks 131 st out of 189 economies on Doing Business indicators for 2014 (World Bank, 2014). The business environment in $\mathrm{B} \& \mathrm{H}$ is the least friendly in the region, as it is burdened by a large and complex public administration system and layers of administrative approval authorities which increases costs (World Bank, 2014).

\subsection{Redirection of Public Expenditures:}

The proposal of the Washington Consensus is that the government should make redistribution of the funds within the budget. Before the transition process the socialist countries were spending a large amount of GDP into military sector development, while neglecting the investment into the education and health sector (Williamson, 1999).

Table 3: Military and Health Care Expenditures in B\&H

\begin{tabular}{|l|c|c|}
\hline & $\begin{array}{c}\text { Military Expenditures } \\
\text { (\% of GDP) }\end{array}$ & $\begin{array}{c}\text { Health Expenditures } \\
\text { (\% of GDP) }\end{array}$ \\
\hline 2002 & 3.6 & 8.1 \\
\hline 2007 & 1.3 & 8.5 \\
\hline 2013 & 1.3 & 9.9 \\
\hline
\end{tabular}

Source: (World Bank Database, 2015).

As it can be seen from Table 3, above, during the transition period $\mathrm{B} \& \mathrm{H}$ made great improvement in shifting funds into more productive sectors for the future. Health expenditures in the regional countries average out around ten percent of gross domestic product (GDP), which implies that the government had some success in the process of redirection of public expenditures (CIA - The World Factbook, 2012). However, the public expenditures for administration are quite high in $\mathrm{B} \& \mathrm{H}$ due to a huge and inefficient administrative system (Pellizer, 2010). 


\subsection{Trade liberalization:}

The trade liberalization is an important element of the Washington Consensus. In that sense, since 1995, Bosnia and Herzegovina had no tariff policy and could be simply depicted as country without borders. Domestic producers have suddenly faced theinternational trade. Foreign goods were cheaper than goods domestically produced by the margin of about 30 percent. Some B\&H economists, Stojanov (2002) argued about the importance of the trade liberalization, stating that trade liberalization is very risky in the case of the post-war country. Stojanov was using the infant economy argument stating that $\mathrm{B} \& \mathrm{H}$ is a post-war country with few natural resources, huge unemployment and obsolete technology, and should protect some industries to catch up with the EU in order to improve the international competitiveness. From a perspective of the economic theory "differing resources endowment, being latecomer, or undergoing reconstruction from war does not in itself constitute a market failure" and does not justify industrial policy (Komiya, 1990: 291). Having in mind the insufficient demand of the country, obsolete technology and fact that the economies of scale are non-existent in any of connected industries, proves that the protection would just keep the economy trapped at the certain level. However, in order to evaluate the trade liberalisation process we present Table 4 . with data of export and import, in selected years.

Table 4: Export and Import of Good and Services in Bosnia and Herzegovina (in millions of current \$US)

\begin{tabular}{|l|l|l|l|l|l|l|}
\hline & 1990 & 1995 & 1999 & 2003 & 2007 & 2012 \\
\hline Exports & 968 & 417 & 1200 & 1794 & 4089 & 5211,3 \\
\hline Imports & 1135 & 1460 & 2725 & 3993 & 8751 & 9359,9 \\
\hline
\end{tabular}

Source: (United Nations, National Accounts Main Aggregates Database, 2005).

From the statistical data provided above, we can conclude that B\&H's exports are much too low. Exports are dominated by raw materials and products intensive in the unskilled labor. Opportunities for participating in the international supply chains, especially within the EU, are insufficiently taken advantage of. In particular sectors where $\mathrm{B} \& \mathrm{H}$ firms are present, such as; textiles and leather products, the long-run sustainability of their participation is threatened by tough competitive pressures, calling for an upgrading and improvement of 
production (World Bank, 2014).

\subsection{Tax Reforms:}

Taxation reform is the recommendation of the Washington Consensus because taxation can provide the government with needed funds for services that can increase the standard of living and spur job creation. However, in $\mathrm{B} \& \mathrm{H}$ the payroll taxes and social contributions are very high and they are a burden for business. For example, if an employer considers paying 1,000 BAM salary, it must pay around 600 BAM to the government in taxes and social contributions. These high taxes are great obstacle to the increase of employment (EU Delegation, 2014).

\section{Graph 4: Taxes on Jobs in EU Countries}

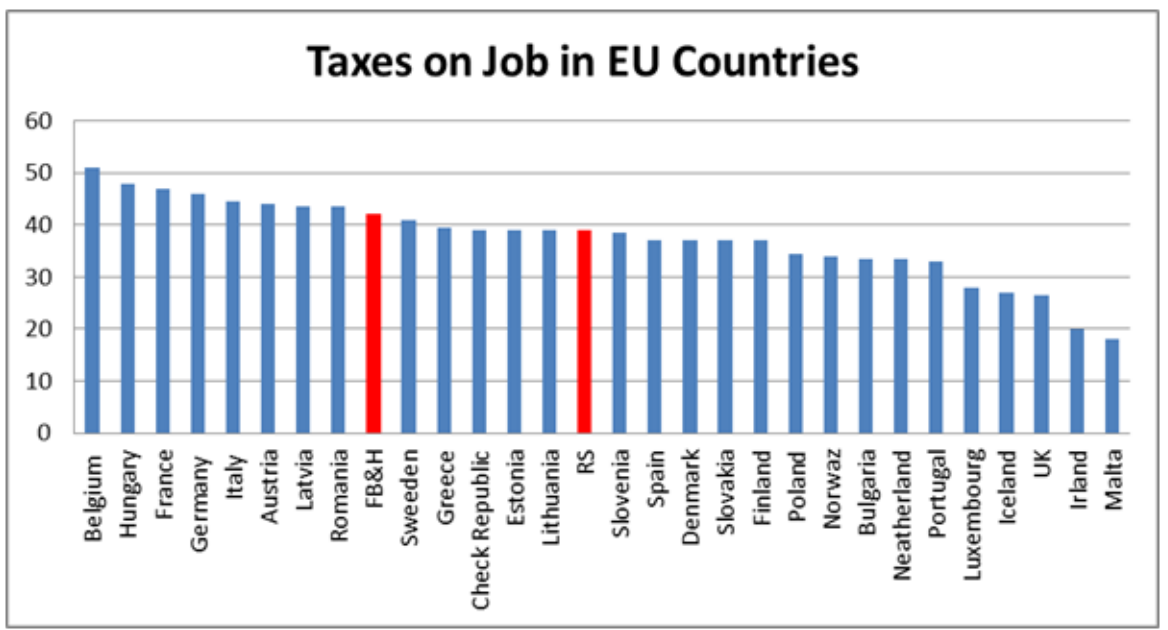

Source: (EU Delegation, Compact for Growth and Jobs, 2014).

By comparing the payroll taxes in Federation of B\&H and RS with other EU countries we may see that, generally, thetaxes in $\mathrm{B} \& \mathrm{H}$ are very high. Other taxes, like profit taxesare reasonable, levying $10 \%$ on the profit. B\&H's government still needs to work on the improvement $2015 / 2$ of its tax base and find the model that will help the employers as well as the employees to reach the better economic future. 


\section{CONCLUSION}

In this paper, we evaluated the recommendations of the Washington Consensus (WC) regarding which structural policies were implemented in B\&H. After deep analysis of all structural policies we can conclude that $\mathrm{B} \& \mathrm{H}$ made a progress, in certain areas, like redirection of the public expenditures by focusing more on health than the defence spending. Privatizations of banking sector, as well as trade liberalisation wereperformed in a proper manner, but domestic exporters were faced with the obstacles caused by the huge administrative barriers, instead of increasing their competitiveness. The implementation of other policies was slow and recommendations were not properly implemented. Privatization of the state enterprises is neither finished,norwas it executed properly. Tax reforms and progress in business deregulations are needed to improve the business environment for domestic as well as for foreign investors. Fiscal discipline and public sectors reforms are necessary in order to make the proper redistribution of budget funds. Furthermore, the improvements of legal system and reduction of corruption are areas where $\mathrm{B} \& \mathrm{H}$ is still behind the Balkan region. This is why the B\&H's government needsa strong leadership in order to move the country forward.

\section{REFERENCES}

Botric, V. (2010). "Foreign Direct Investment in the Western Balkans: Privatization, Institutional Change and Banking Sector Dominance”. Economic Annals, 55 (187), 7-30.

Centers for Civic Initiatives (2014)."Monitoring of the Government of FB\&H 2011 2014". Available from: <http://www.cci.ba/dokumenti/Summary_Government_ FBiH_english.pdf $>$. [October, 2015].

Central Intelligence Agency (CIA). (2015). "The World Factbook: Health Expenditures the-world-factbook/rankorder/2225rank.html>. [November, 2015].

Dapo, E. \& Ridic, O. (2015). "Washington Economic Agreement and the Implementation of Fiscal Discipline, Currency Board and Stable Exchange Rate in Bosnia and Herzegovina". Paper presented at the International Research Congress on Social Sciences, Sarajevo.

Demekas, D.G., Horvath, B., Ribakova, E. \& Wu, Y. (2005). "Foreign Direct Investment in Southeastern Europe: How (and How Much) Can Policies Help?".IMF Working Paper.Available from: <https://www.imf.org/external/pubs/ft/wp/2005/ 
wp05110.pdf>. [December, 2015].

EU Delegation in Bosnia and Herzegovina. (2014). "Compact for Growth and Jobs Brochure,European Bank for Reconstruction and Development, various years, Transition Reports". Available from: <http://www.ebrd.com/home>. [September, 2015].

Foreign Investment Promotion Agency of Bosnia and Herzegovina (FIPA). (2012). "Investment Opportunities in Bosnia and Herzegovina". Available from: <http://www. sarajevo.ba/ba/files/bcentar/investment-opportunities-fipa.pdf>. [September, 2015].

Foreign Investment Promotion Agency of Bosnia and Herzegovina (FIPA). (2014). "Macroeconomics Indicators". Available from: <http://www.fipa.gov.ba/informacije/ statistike/pokazatelji/default.aspx?id=206\&langTag=en-US $>$. [September, 2015].

Handjinski, B. (2009). "Investment matters: The role and patterns of investments in Southeastern Europe”, World Bank Working Paper, No. 159. Available from:

$<$ https://openknowledge.worldbank.org/bitstream/

handle/10986/5920/473990PUB0Inve101OFFICIAL0USE0ONLY1.

pdf? sequence $=1$ \&isAllowed $=y>$. [October, 2015].

Ilgun, E. \& Coskun, A. (2009). "Foreign Direct Investments in Bosnia and Herzegovina: Banking sector example”. Alatoo Academic Studies, 4 (2), 49-67.

Kapur, D. (1998). “The IMF: A Cure or a Curse”. Foreign Policy, 111, 114-126.

Kohama, H. (2003). "External Factor for Asian Development”. Institute of Southeast Asian Studies.

Ministry of Foreign Trade and Economic Relations (MFTER). (2007). “Trade related needs assessment report", Sarajevo.

Office of the High Representative (OHR). (1999). "Annex to Final Award, Arbitration for the Brcko Area". Available from: <http://www.ohr.int/ohr-offices/brcko/default. asp?content_id=5362>. [September, 2015].

Ohno, K. \& Ohno, I. (1998). “Japanese Views on Economic Development: Diverse Paths to the Market”. Routledge.

Pellizer, V. (2010). "Time for Action: Responding to Poverty, Social Exclusion and Inequality in Europe and Beyond". European Social Watch Report.

Stiglitz, J. (2002). “Globalization and its Discontents”. W. W. Norton, New York.

Stojanov, D. (2000). "Supply Side Industrial Strategy: The Case of Bosnia and Herzegovina”. Cooperation South, 2, 64-84.

Williamson, J. (1999). "Economic Reform: Content, Progress, Prospects". Paper Presented at the 50th Anniversary Celebration of the University of Baroda, India. 
World Bank Group. (2014). "Bosnia and Herzegovina Partnership: Country Program snapshot 2014”. http://www.worldbank.org.ba.

World Bank Group. (2014). "Doing Business 2014, Economy Profile: Bosnia and Herzegovina”. Report. Available from: <http://www.doingbusiness.org/data/ exploreeconomies/bosnia-and-herzegovina/>. [September, 2015].

World Bank. (1996). "Bosnia and Herzegovina - The priority reconstruction and recovery program: the challenges ahead". World Bank Report.

Yanagihara, T. (1998). "Development and Dynamic Efficiency: 'Framework Approach' versus 'Ingredient Approach". .In: Kenichi \& Izumi [eds.] Japanese Views on Economic Development: Diverse Paths to the Market. , Routledge, chapter 4. 